\title{
ГЛАВА VII \\ ОРГАНІЗАЦІЯ ТА МЕТОДИЧНІ ПРИЙОМИ ДЕРЖАВНОГО ФІНАНСОВОГО АУДИТУ В УМОВАХ НЕВИЗНАЧЕНОСТІ ТА РИЗИКУ
}

Процес організації держсавного фінансового аудиту. Організація процесу державного фінансового аудиту передбачає три стадії його проведення: забезпечення контрольних дій, основна, підготовка звіту за результатами перевірки (табл. 7.1).

Таблиия 7.1

Організація процесу ДФА

\begin{tabular}{|c|c|c|c|c|}
\hline $\begin{array}{l}\text { № } \\
\text { 3/II }\end{array}$ & $\begin{array}{c}\text { Контрольний } \\
\text { процес }\end{array}$ & Завдання & $\begin{array}{c}\text { Контрольні } \\
\text { заходи } \\
\end{array}$ & $\begin{array}{c}\text { Документальний } \\
\text { супровід }\end{array}$ \\
\hline 1. & $\begin{array}{l}\text { Вибір } \\
\text { аудиторського } \\
\text { завдання та } \\
\text { обстеження } \\
\text { об'єкта } \\
\text { (попереднє } \\
\text { ознайомлення } 3 \\
\text { підконтрольним } \\
\text { об'єктом (вибір } \\
\text { проблеми для } \\
\text { аудиту) }\end{array}$ & $\begin{array}{l}\text { - збір інформації про } \\
\text { проблему; } \\
\text { - визначення ракурсу } \\
\text { цієї проблеми з погляду } \\
\text { контролю; } \\
\text { - прийняття рішення } \\
\text { про початок } \\
\text { проведення державного } \\
\text { фінансового аудиту; } \\
\text { - попереднє планування } \\
\text { проведення державного } \\
\text { фінансового аудиту }\end{array}$ & $\begin{array}{l}\text { - відбір } \\
\text { найбільш } \\
\text { важливих і } \\
\text { значущих } \\
\text { напрямів } \\
\text { перевірки; } \\
\text { - проведення } \\
\text { попереднього } \\
\text { опитування }\end{array}$ & $\begin{array}{l}\text { Меморандум } \\
\text { про результати } \\
\text { попереднього } \\
\text { ознайомлення }\end{array}$ \\
\hline 2. & $\begin{array}{l}\text { Планування } \\
\text { державного } \\
\text { фінансового } \\
\text { аудиту }\end{array}$ & $\begin{array}{l}\text { Системно організувати } \\
\text { роботу державних } \\
\text { аудиторів }\end{array}$ & $\begin{array}{l}\text { Складання } \\
\text { програми, } \\
\text { в якій } \\
\text { здійснюється: } \\
\text { - визначення } \\
\text { масштабу } \\
\text { аудиту; }\end{array}$ & $\begin{array}{l}\text { План та програма } \\
\text { державного } \\
\text { фінансового } \\
\text { аудиту. До } \\
\text { програми } \\
\text { додається } \\
\text { табличний } \\
\text { матеріал, схеми, }\end{array}$ \\
\hline
\end{tabular}


Продовження таблиці 7.1

\begin{tabular}{|c|c|c|c|c|}
\hline 2. & $\begin{array}{l}\text { Планування } \\
\text { державного } \\
\text { фінансового } \\
\text { аудиту }\end{array}$ & $\begin{array}{l}\text { Системно } \\
\text { організувати } \\
\text { роботу } \\
\text { державних } \\
\text { аудиторів }\end{array}$ & $\begin{array}{l}\text { - формулювання } \\
\text { робочої гіпотези; } \\
\text { - визначення } \\
\text { критеріїв оцінки; } \\
\text { - визначення } \\
\text { методів збирання } \\
\text { і опрацювання } \\
\text { даних }\end{array}$ & $\begin{array}{l}\text { розроблений } \\
\text { інструментарій } \\
\text { розрахунків } \\
\text { показників } \\
\text { ефективності, } \\
\text { результативності, } \\
\text { економічності }\end{array}$ \\
\hline 3. & Оцінка системи & $\begin{array}{l}\text { Оцінити } \\
\text { ефективність } \\
\text { функціонування } \\
\text { систем }\end{array}$ & $\begin{array}{l}\text { Проводиться } \\
\text { - оцінка } \\
\text { структурних } \\
\text { змін, які } \\
\text { відбуваються } \\
\text { в економічних } \\
\text { системах країни, } \\
\text { нових тенденцій } \\
\text { та розвитку } \\
\text { окремих } \\
\text { ринкових } \\
\text { сегментів; } \\
\text { - оцінка системи } \\
\text { внутрішнього } \\
\text { контролю }\end{array}$ & \\
\hline
\end{tabular}

Отже, на відміну від аудиту діяльності суб’єктів господарювання, та 3 урахуванням впливу ризиків повинна включати три контрольні процеси, які передують безпосередньому проведенню аудиту:

1. Вибір аудиторського завдання та обстеження об'єкта (попереднє ознайомлення 3 підконтрольним об'єктом (вибір проблеми для аудиту).

Попереднє ознайомлення 3 підконтрольним об’єктом $\epsilon$ основою для прийняття рішень про початок проведення державного фінансового аудиту. 
Завданнями попереднього ознайомлення є:

- збір інформації про проблему;

- визначення ракурсу цієї проблеми з погляду контролю;

- прийняття рішення про початок проведення державного аудиту;

- попереднє планування проведення державного фінансового аудиту.

Критерієм вибору проблеми для аудиту є ситуації двох типів: негативні ситуації в тій чи іншій галузі (сфері, державній програмі) та ситуації необхідності оцінки економічності, ефективності, результативності тієї чи іншої державної структури або бюджетної програми. Таких проблем у суспільстві, яке розвивається, можна виявити значну кількість. Тому, перед ініціатором контролю постає питання відбору найбільш важливих і значущих напрямів перевірки. Відбір можна здійснити, користуючись критеріями, найважливіші 3 яких такі:

- важливість проблеми (матеріальність, як розмір виконаних коштів для громадянського суспільства, ступінь ризику, тип проблеми (структурна, довготривала));

- можливість проведення державного фінансового аудиту (наявність методик, ресурсів, кваліфікованого персоналу);

- потенціал змін (рішення, які впливатимуть на подальші дії, зацікавленість у змінах (уряду, виконавчої влади, парламентаріїв, об'єкта перевірки)).

Аналіз наукових розробок із проблем ДФА засвідчив відсутність науково обгрунтованої методики вибору тем і об'єктів ДФА, які б на основі рейтингової оцінки дозволили б отримати більше розуміння та необхідність перевірки (аудиту) відповідної теми та об'єкту. 
Більшість державних аудиторів вибирають, які перевірки повинні бути проведені, на основі своїх посадових обов'язків. Оскільки об'єктів, що підлягають аудиту, дуже багато, то можна застосовувати певні критерії для вибору видів діяльності чи бюджетних організацій для перевірки. Ці критерії узагальнено включають:

1) економічне чи політичне значення;

2) розмір у грошовому чи іншому кількісному вираженні;

3) притаманний високий рівень ризику;

4) наявність повідомлень про неналежну чи слабку систему контролю та безпеки;

5) запити від Верховної Ради про проведення перевірки певного об'єкту.

Також, слід застосовувати принцип «ротації» при виборі об'єктів аудиту. За допомогою цього забезпечується те, що всі державні витрати та бюджетні установи вибираються для перевірки у рівні проміжки часу. При остаточному виборі об'єктів аудиту також враховується наявність належно кваліфікованих аудиторів та часовий фактор.

Кінцевим результатом попереднього ознайомлення $\epsilon$ меморандум, в якому на основі отриманої та проаналізованої інформації обгрунтовується проблема для аудиту, приймається рішення про його проведення на конкретному об'єкті.

Проводячи попереднє опитування, аудитори мають на меті одержати основну інформацію про всі аспекти діяльності, що підлягають перевірці. При попередньому опитуванні передбачається одержання не доказів, а лише інформації, необхідної для розробки реалістичного плану аудиту.

Попереднє опитування може проводитися як на об'єкті аудиту, 
так і без виїзду на об’єкт. Висновок опитування повинен включати:

1. мету діяльності чи програми;

2. місце розташування організаціі;

3. структуру управління організацією, порядок здійснення діяльності або механізми реалізації програми;

4. історію організації чи здійснення певної діяльності;

5. існуючі нормативно-правові вимоги;

6. кількість працівників;

7. загальну стратегію та політику;

8. огляд систем контролю та управління діяльності;

9. бюджет та фінансові показники за попередній період;

10. висновки будь-якої попередньої перевірки.

Під час попереднього опитування також, доцільно, проводити певний аналіз з метою одержання вихідних даних для подальшої оцінки ефективності.

Уже наприкінці попереднього опитування аудитор може визначити певні недоліки чи проблеми. Це матиме вплив на його конкретну аудиторську роботу, покликану підтвердити чи спростувати виниклі підозри в тому, що ці недоліки та проблеми призвели до значних порушень (відхилень) від законності або нормативів (стандартів).

Іноді, якщо висновки попереднього опитування (наприклад, про відсутність стратегіï) є достатніми і не потребують подальшої аудиторської роботи, аудитор може завершити роботу щодо причинно-наслідкового аналізу ситуації вже на цьому етапі.

У деяких випадках, передбачених законодавством, документальна підготовка до здійснення ревізії закінчується інформуванням керівництва суб’єкта господарювання про намір проведення контрольних заходів. 
Таким чином, попереднє опитування має важливе значення для розробки плану аудиту, даючи аудитору змогу швидко визначити аспекти, істотні для аудиторських висновків.

2. Планування ДФА.

Планування державного фінансового аудиту передбачає складання програми, яка має специфічні складові:

- визначення масштабу аудиту;

- формулювання робочої гіпотези;

- визначення критеріїв оцінки;

- визначення методів збирання і опрацювання даних.

Масштаб аудиту передбачає складання переліку питань та підконтрольних об’єктів, а також обмежень, які державні аудитори мають застосовувати, щоб зосередитись на найважливіших аспектах.

Визначаючи питання перевірки, аудитори керуються виключною важливістю для забезпечення ефективності використання державних коштів об’єктами контролю, великим значенням 3 точки зору досягнення запланованих результатів. Питання мають бути сформульованими таким чином, щоб була можливість їх перевірити власними ресурсами контролюючого органу. Наприклад, якщо метою державного фінансового аудиту є перевірка організації діяльності підконтрольного об’єкта щодо виконання ним функції або завдання, формулюють наступні питання:

1. снують в установі чітко визначені цілі їі діяльності, розроблено плани чи організаційні заходи їх реалізації?

2. Затверджені в установі якісні та кількісні показники оцінки результатів її діяльності щодо досягнення поставлених цілей?

3. Встановлені керівництвом показники, що забезпечують реалізацію плану у визначені терміни?

4. Розглядалися керівництвом альтернативні варіанти 
досягнення поставлених цілей?

5. Розуміють співробітники цілі і пріоритети діяльності установи, свої завдання, існує система стимулювання співробітників за якісне виконання обов'язків?

6. Здійснюється в установі постійний внутрішній контроль результатів діяльності?

Відбір об'єктів аудиту (як правило, це бюджетні кошти, виділені для виконання бюджетної програми) відбувається не 3 метою виявлення порушень фінансової дисципліни, а для оцінки досягнутих результатів внаслідок освоєння виділених коштів, для визначення додаткових заходів, які б могли суттєво підвищити виконання програми. Якщо сфера перевірки охоплює діяльність декількох міністерств, обирають ті з них, які є репрезентативними, щоб результати перевірки були поширеними на всю сферу діяльності.

Крім критеріїв формування репрезентативної вибірки для державного аудиту, слід використовувати чинники обмеження підконтрольного об'єкта за географічним розташуванням та часовими обмеженнями. Приклад відбору об’єктів для державного фінансового аудиту наведено у табл. 7.2.

Таблиияя 7.2

\section{Визначення масштабу державного фінансового аудиту}

\begin{tabular}{|l|l|}
\hline Аспект & Приклад масштабного обмеження \\
\hline Об’єкт & $\begin{array}{l}\text { Міністерство або вся галузь, регіональний рівень (область, } \\
\text { райони) }\end{array}$ \\
\hline $\begin{array}{l}\text { Географічні } \\
\text { обмеження }\end{array}$ & Регіони, кількість областей і які саме, кількість районів і які саме \\
\hline $\begin{array}{l}\text { Часові } \\
\text { обмеження }\end{array}$ & $\begin{array}{l}\text { Стан до початку роботи програми, термін дії програми, термін } \\
\text { після закінчення фінансування для оцінки результатів }\end{array}$ \\
\hline
\end{tabular}

Важливою відмінністю планування державного фінансового аудиту від інших перевірок є формулювання робочої гіпотези, 
пов’язаної з проблемою для аудиту.

Гіпотеза (сформульоване припущення) виражає завдання аудиту і спирається на аналіз проблеми, підготовлений попереднім ознайомленням, зумовлена емпіричними результатами або логічними міркуваннями. Особливості гіпотези полягають в іiі характеристиках: релевантність, можливість перевірки, переважно негативне формулювання (на відміну від фінансової ревізії, яка визначається неупередженістю).

Гіпотеза заздалегідь визначає негативну організацію процесу витрачання бюджетних коштів. Згодом гіпотеза або підтверджується, або відхиляється. Безсумнівним є лише одні подібні негативні характеристики, притаманні гіпотезі аудиту, грунтуються на заздалегідь проведених дослідженнях на попередньому етапі i отриманої інформації про негативні результати реалізації державної програми. У прикладі державного фінансового аудиту програми інформатизації сільських шкіл, такою інформацією були завищені ціни придбаної комп'ютерної техніки, неробочий стан комп’ютерів через неможливість технічного обслуговування тощо.

Отже, під гіпотезою ДФА слід розуміти припущення аудитора (здогад) щодо причини виникнення та існування проблем, недосконалості певних позицій в організації виконання бюджетної програми.

В якості гіпотез ДФА можливо також розглядати:

- недосконалість законодавчо-правової забезпечення;

- відсутність (недосконалість) звітності про виконання бюджетної програми.

Визначення гіпотези на стадії планування або в меморандумі 
про результати попереднього ознайомлення 3 проблемою має важливе значення саме через спрямування контрольних дій у потрібному напрямі. За умов невідповідного формулювання гіпотези можливі окремі негативні результати під час подальших дій контролерів, які призводять до зайвого витрачання ресурсів контролюючого органу.

Отже, наслідки неналежної організації державного фінансового аудиту представлено в табл. 7.3.

Таблиияя 7.3

\section{Наслідки неналежної організації державного фінансового} аудиту

\begin{tabular}{|c|c|c|}
\hline $\begin{array}{l}\text { № } \\
\text { 3/II }\end{array}$ & $\begin{array}{c}\text { Умови планування та } \\
\text { проведення аудиту }\end{array}$ & Наслідки \\
\hline 1. & $\begin{array}{l}\text { Нормальне виконання } \\
\text { державного фінансового аудиту }\end{array}$ & $\begin{array}{l}\text { Призводить до реалізації } \\
\text { гіпотетичних уявлень про проблему } \\
\text { аудиту у вигляді висновків і } \\
\text { рекомендацій }\end{array}$ \\
\hline 2. & $\begin{array}{l}\text { Недооцінка проблеми на } \\
\text { етапі попереднього аудиту } \\
\text { або формулювання гіпотези } \\
\text { за умови надто емоційного } \\
\text { роздування проблеми }\end{array}$ & $\begin{array}{l}\text { Обсяги контрольних дій або об’єкти } \\
\text { аудиту невиправдано збільшуються, } \\
\text { що не передбачалось на етапі вибору } \\
\text { проблеми аудиту }\end{array}$ \\
\hline 3. & $\begin{array}{l}\text { Хибне визначення проблеми } \\
\text { під час планування або } \\
\text { помилкового формулювання } \\
\text { гіпотези, наявність значного } \\
\text { впливу на контрольні дії під час } \\
\text { перевірки }\end{array}$ & $\begin{array}{l}\text { Призводять до викривлення дій в } \\
\text { сторону. Наслідками такої зміни мети } \\
\text { є низька результативність аудиту і } \\
\text { невиконання мети перевірки, хоча } \\
\text { при цьому виявляються інші важливі } \\
\text { проблеми }\end{array}$ \\
\hline 4. & $\begin{array}{l}\text { Гіпотези, визначені під час } \\
\text { попереднього ознайомлення в } \\
\text { процесі втратили релевантність }\end{array}$ & $\begin{array}{l}\text { Звуження обсягу контрольних дій } \\
\text { державного фінансового аудиту }\end{array}$ \\
\hline
\end{tabular}

Наступною складовою процесу планування державного фінансового аудиту є визначення критеріїв оцінки ефективності, економічності, результативності, якості послуги та фінансової 
діяльності об'єкта перевірки. Єдиного підходу до визначення таких критеріїв немає через різноманітні об'єктів аудиту та цілей, які досягаються в результаті йоги проведення.

Критерії оцінки - це обгрунтовані показники роботи i контролю, на підставі яких здійснюють аналіз ефективності реалізації програм, здійснення видів діяльності, економічних операцій. Вони розробляються для кожної установленої мети i конкретних аспектів діяльності підконтрольної установи, кожної програми витрачання державних коштів.

Критерії, обрані для оцінки ефективності використання державних коштів, слід обговорити з розпорядником державних коштів, який підлягає перевірці. Право вибору критеріїв належить державним аудиторам, але вони повинні враховувати заперечення i думку керівництва підконтрольного об'єкта.

Під час проведення державного фінансового аудиту можуть виникати нові питання, які потребуватимуть перегляду прийнятих критеріїв оцінки. В таких випадках керівник перевірки приймає рішення щодо коригування визначених показників, при цьому в аудиторському звіті слід обов'язково розшифрувати причини та наслідки таких змін.

Планування передбачає визначення методів збирання i опрацювання даних. Державні аудитори обирають i коротко описують методи проведення державного фінансового аудиту, за якими здійснюватиметься збір фактичних даних i доказів. Особливістю такої форми контролю $є$ посилення аналітичної складової контрольних дій. Окрім традиційних методів документального і фактичного контролю, широко використовують методи SWOT-аналізу, бенчмаркінгу, аналізу затрат і результатів, аналізу чутливості, економічну оцінку господарських операцій, 
а також методи анонімного анкетування, опитування споживачів i виконавців, вивчення інформації у публікаціях ЗМІ.

Планування роботи 3 інформацією та їі опрацювання має забезпечити уніфікацію джерел, змісту, виду інформації, яку слід зібрати та використати в якості доказів, порядок контролю за їх достовірністю.

Результатом проведеної підготовчої роботи та планування e програма державного фінансового аудиту, яка в процесі обговорення 3 представниками головного розпорядника державних коштів (підконтрольного об'єкта) уточняється та затверджується. До програми додається табличний матеріал, схеми, розроблений інструментарій розрахунків показників ефективності, результативності, економічності.

Зміст плану аудиту повинен включати:

1) правові рамки аудиту;

2) стислий опис об'єкту аудиту;

3) підсумки минулих аудитів;

4) чинники, що впливають на аудит - визначені ризики;

5) цілі аудиту;

6) погоджений масштаб аудиту:

а) аспекти систем, які повинні бути перевірені;

б) план тестування чи вибірки;

в) суттєвість - грошова сума;

7) кадрові ресурси - аудитори, спеціалісти;

8) прізвища працівників міністерства, 3 якими зв'язуватиметься аудитор;

9) графік проведення аудиту;

10) формат аудиторського висновку.

Строкипроведення перевірки ефективностітаспіввідношення 
витрат часу між іiї етапами залежать, насамперед, від предмету, цілей і масштабу кожної конкретної перевірки, а також обсягу фінансових ресурсів і кількості фахівців, виділених для їі проведення.

Кожен етап проведення аудиту ефективності включає низку послідовних дій, результати яких оформлюються у відповідних документах.

У зарубіжних країнах (Великої Британії, Канади, США, Франції та ін.), як показує досвід органів державного фінансового контролю, одна перевірка ефективності проводиться, в середньому протягом 12-14 місяців.

При цьому час між іï основними етапами розподіляється, зазвичай, на три рівні частини. Виходячи з цього, рекомендується під час планування аудиту ефективності, визначення його етапів і термінів проведення використовувати зразок графіку проведення ДФА, представлений у таблиці 7.4.

Таблиияя 7.4

Зразок графіку проведення ДФА

\begin{tabular}{|c|c|c|}
\hline Стадія & Дiii & Терміни (щорічно) \\
\hline \multirow{6}{*}{ Організація ДФА: } & - вибір теми й об’єктів перевірки & листопад - грудень \\
\hline & $\begin{array}{l}\text { - складання плану попереднього вивчення } \\
\text { теми й об’єктів перевірки }\end{array}$ & січень \\
\hline & - збір необхідної інформації та матеріалів & січень - березень \\
\hline & $\begin{array}{l}\text { - підготовка звіту про результати } \\
\text { попереднього вивчення }\end{array}$ & квітень \\
\hline & - підготовка програми перевірки & квітень \\
\hline & $\begin{array}{l}\text { - складання робочого плану проведення } \\
\text { перевірок }\end{array}$ & квітень \\
\hline \multirow{3}{*}{$\begin{array}{l}\text { Здійснення } \\
\text { перевірки } \\
\text { (верифікація): }\end{array}$} & $\begin{array}{l}\text { - збір фактичних даних і доказів на } \\
\text { об’єктах перевірки }\end{array}$ & травень - серпень \\
\hline & $\begin{array}{l}\text { - підготовка висновків і рекомендацій за } \\
\text { результатами перевірки }\end{array}$ & вересень \\
\hline & $\begin{array}{l}\text { - ознайомлення керівництва } \\
\text { перевірених об’єктів із результатами } \\
\text { перевірки }\end{array}$ & вересень \\
\hline
\end{tabular}


Продовження таблиияі 7.4

\begin{tabular}{|c|c|c|}
\hline \multirow{3}{*}{$\begin{array}{l}\text { Підготовка звіту } \\
\text { про результати } \\
\text { перевірки: }\end{array}$} & $\begin{array}{l}\text { - підготовка попереднього проекту звіту } \\
\text { про результати перевірки }\end{array}$ & жовтень \\
\hline & $\begin{array}{l}\text { - підготовка остаточного варіанту звіту } \\
\text { про результати перевірки з урахуванням } \\
\text { зауважень і пропозицій }\end{array}$ & листопад \\
\hline & $\begin{array}{l}\text { - подання звіту про результати перевірки } \\
\text { на розгляд Колегії Рахункової палати }\end{array}$ & грудень \\
\hline
\end{tabular}

Для забезпечення економного планування аудиту важливе значення має розробка часового графіку та кошторису.

Витрати часу розраховуються, виходячи із кількості днів перевірки, терміну роботи в день та кількості аудиторів, а на етапі планування - уточняються.

Витрати часу і кількісний склад групи сплануємо таким чином:

14 днів х 7 годин х $3=294$ годин (табл. 7.5).

Таблиия 7.5

Планування уточнення обсягу робіт та бюджету витрат часу

\begin{tabular}{|l|c|c|c|c|}
\hline \multirow{2}{*}{\multicolumn{1}{c|}{ Об'єкти перевірки }} & \multicolumn{3}{|c|}{ Витрати часу } & \multirow{2}{*}{ Разом } \\
\cline { 2 - 4 } & Асистент & $\begin{array}{c}\text { Молодший } \\
\text { аудитор }\end{array}$ & $\begin{array}{c}\text { Старший } \\
\text { аудитор }\end{array}$ & \\
\hline Грошові кошти & 20 & - & 5 & 25 \\
\hline Дебітори & - & 50 & 5 & 55 \\
\hline Кредитори & 15 & 25 & 4 & 44 \\
\hline Довгострокова заборгованість & 10 & 20 & 5 & 35 \\
\hline Поточні зобов'язання & 10 & 20 & 5 & 35 \\
\hline Прострочена заборгованість & 5 & 10 & 5 & 20 \\
\hline Доходи і витрати & - & - & 10 & 10 \\
\hline Прибуток & - & - & 10 & 10 \\
\hline Планування, контроль & & - & 10 & 10 \\
\hline Звіти & - & - & 10 & 10 \\
\hline Оподаткування & 20 & - & 10 & 30 \\
\hline Формування справи & - & - & 10 & 10 \\
\hline Разом & 80 & 125 & 89 & 294 \\
\hline
\end{tabular}


Цей документ готується на підготовчій стадії та на стадії здійснення аудиту [1, с. 86].

\section{3. Оиінка систем.}

Суб’єкт контролю, який бере участь у здійсненні державного фінансового аудиту державних фінансових потоків, виконує оцінку структурних змін, які відбуваються в економічних системах країни, нових тенденцій та розвитку окремих ринкових сегментів. У такому разі проблеми фінансових потоків вчасно можуть потрапити для розгляду до аудиторів з погляду їх ефективності.

Аудитор також оцінює системи внутрішнього контролю, але перед тим розглядає сутність та призначення таких систем. Структура системи внутрішнього контролю складається 3 планів та заходів організації, спрямованих на:

1) сприяння впорядкованій, економічній, ефективній і дієвій діяльності з наданні якісних послуг відповідно до мети діяльності організації;

2) дотримання вимог національних законодавчих i нормативних актів, а також наказів та розпоряджень керівництва;

3) збереження ресурсів від збитків внаслідок зловживань, нецільового використання, халатності, помилок, шахрайства та інших порушень. Цільове використання бюджетних коштів відноситься до основних принципів бюджетної системи України, що викладені в статті 7 Бюджетного кодексу України: «бюджетні кошти використовуються тільки на цілі, визначені бюджетним призначеннями» [2];

4) розробку та підтримку надійної фінансової й управлінської інформації, наддостовірне відтворення такої інформації у своєчасних висновках.

Поняття ризику, на противагу поняттю невизначеності, має 
практичне застосування, а тому його зміст потребує об'єктивного визначення. Отже, потрібний перехід від суб’єктивно сприйманої непевності, випадковості до об’єктивного поняття ризику, що на ній базується. Єдиний спосіб такого переходу - оцінити непевність (випадковість) кількісними методами, надавши їй реальних числових значень. Звідси випливає: ризиком буде визнано лише таку невизначеність, яку можна оцінити кількісно.

Дати найточнішу кількісну оцінку невизначених величин можна, обчисливши ймовірність їх появи. Ця ймовірність має ту характерну особливість, яка враховує одночасно два необхідні компоненти загальної оцінки взаємодоповняльної випадковості:

- частоту настання події щодо місця та часу;

- розмір збитку, тобто абсолютну величину від'ємного відхилення фактичного результату від очікуваного.

Отже, показник ризику за своїм змістом - це не лише ймовірність появи непевної (випадкової) події, а й імовірність настання негативного результату.

Невизначеність - це відсутність достатньої інформації про можливі події. Вона зумовлює ризик, тобто можливість відхилення фактичних результатів від очікуваних. Чим більша невизначеність, тим більший ризик при прийнятті рішення.

Рішення невизначеності характеризується браком або повною відсутністю інформації про процеси, явища, вплив окремих факторів на діяльність підприємства.

Згідно підходу, що застосовується фахівцями консалтингової фірми McKinsey, існує чотири рівні невизначеності:

- рівень 1 (досить ясне майбутнє) - можливість передбачення лише одного прогнозу майбутнього, досить точного для розробки стратегї; 
- рівень 2 (альтернативні варіанти майбутнього) - майбутнє прогнозується у вигляді одного з декількох альтернативних варіантів розвитку подій або альтернативних сценаріїв;

- рівень 3 (широкий діапазон варіантів майбутнього) прогнозується діапазон потенційних можливостей, обмежених часом;

- рівень 4 (повна невизначеність) - прогнозування неможливе.

Чим більший рівень невизначеності, тим нижча якість управлінських рішень та ефективність дій. Тому необхідно мінімізувати (в ідеалі - звести нанівець) невизначеність для підвищення якості управлінського впливу за рахунок структурування інформації про ситуацію всередині та навколо підприємства, тобто виокремити визначені та невизначені параметри, дібрати методи підвищення визначеності останніх і т. ін. Зменшення невизначеності сприяє впорядкуванню діяльності керівників підприємства, дає їм змогу розробляти рішення щодо адаптації організації та окремих іiі підсистем до змін ситуації [3, с. 187-188].

У процесі організації ДФА спостерігаються ситуації невизначеності, які спричиняють ризики і впливають на процедуру iї планування, перешкоджають (можуть перешкоджати) досягненню поставлених перед органами ДФА цілей, можуть призвести до наступних наслідків:

- недотримання встановлених регламентів організації i планування ДФА, що в свою чергу призводить до несвоєчасного та неякісного виконання інших етапів роботи;

- низька якість підготовлених документів;

- відволікання людських, часових та інших ресурсів на здійснення численних коригувань, виконання додаткових завдань, які мають мінімальну цінність на етапі планування ДФА та результати 
яких не використовуються;

- зниження рівня системності державного фінансового аудиту, не в повному обсязі виконання завдань, поставлених перед органами ДФА.

Відповідно до основних етапів організації і планування ДФА ризики доцільно сформувати у 4 групи (рис. 7.1).

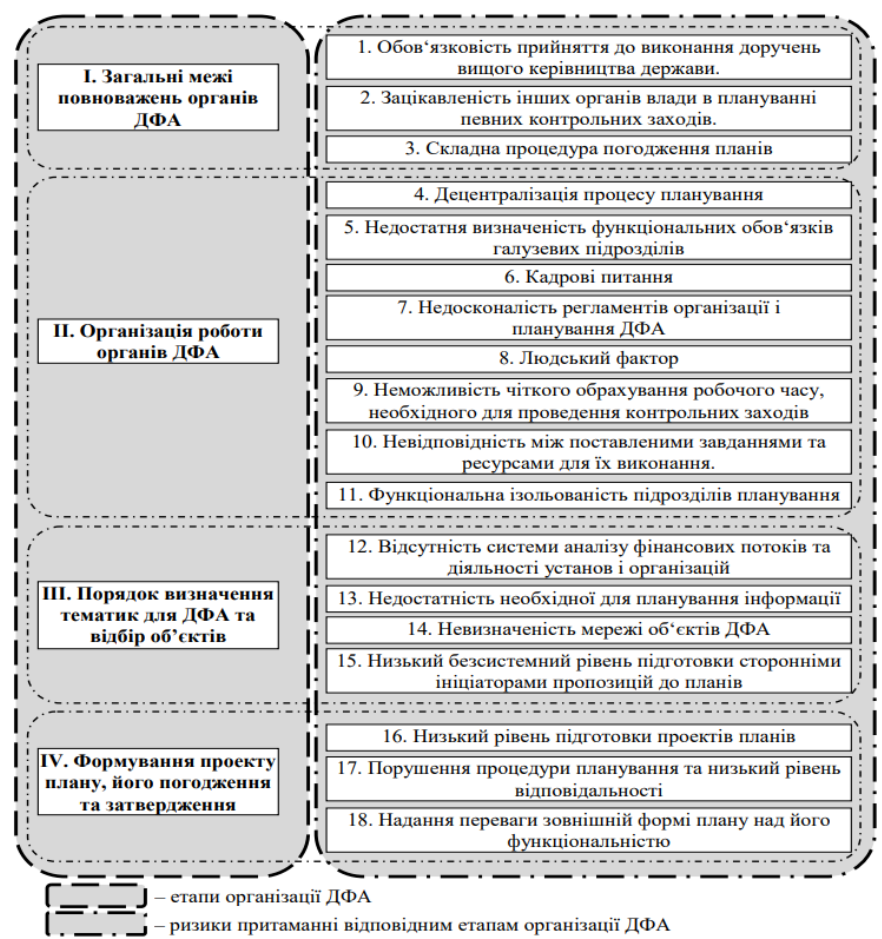

\section{Рис. 7.1. Класифікація ризиків відповідно до етапів організації} та планування ДФА

\section{І. ЗАГАЛЬНІ МЕЖІ ПОВНОВАЖЕНЬ ОРГАНІВ ДФА}

1. Обов'язковість прийняття до виконання доручень вищого керівництва держави. Відсутність зворотного зв'язку вимагає включати до планів навіть завідомо без результативні перевірки. Значна кількість таких доручень ставить органи ДФА у жорсткі часові 
рамки як на стадії організації роботи, так і на етапі їі виконання.

Крім того, вказане не дозволяє в повній мірі реалізовувати повноваження Служб, оскільки можливості щодо організації контрольних заходів за власною ініціативою мінімізуються, інформація, що стала відома органам ДФА під час виконання основних завдань, виявляється непотрібною.

2. Зацікавленість інших органів влади в плануванні контрольних заходів.

Враховуючи визначений законодавством статус органів ДФА та інших державних органів, багато часових, людських та інших ресурсів витрачається на узгодження з цими органами проєкту плану в частині неможливості (не підконтрольність, відсутність у реєстрах або за вказаною адресою) або недоцільності (малий період аудиту, незначні обсяги державних ресурсів) проведення контрольних заходів, а також на їх подальше виключення із затвердженого плану.

3. Складна процедура погодження планів.

Так, основні напрями ДФА проходять процедуру погодження 3 державними органами-ініціаторами (вимоги більшості з яких $є$ обов'язковими для виконання), погоджуються на Методологічних радах та Колегіях, затверджуються Кабінетом Міністрів тощо. Крім того, на кожному етапі планування (в Рахунковій палаті, Мінфіні, Кабміні тощо) внаслідок редакторських правок суть пропозицій до плану нівелюється все більше і більше (зокрема, часто втрачаються особливості, за яких тема чи об'єкт потребує безумовного включення до плану - дані про отримання об'єктом бюджетних коштів).

\section{II. ОРГАНІЗАЦІЯ РОБОТИ ОРГАНІВ ДФА}

4. Децентралізація процесу планування.

Ризик пов'язаний 3 тим, що пропозиції до планів ДФА самостійно готуються всіма підрозділами та в регіонах. Внаслідок 
цього підрозділи організаційної роботи фактично не мають впливу на результати планування ДФА, а виконують лише функції узагальнення та редагування проєктів планів. У той же час, звітування за дорученнями керівництва держави покладено саме на підрозділи оргроботи.

5. Недостатня визначеність функціональних обов'язків галузевих підрозділів.

Визначається впливом структури галузевих підрозділів та розподілу їх функціональних обов'язків на організацію роботи та, як наслідок, іï якість. Зокрема, вказане простежується:

- відділи аудиту існують в усіх галузевих підрозділах, що призвело до функціональних суперечок 3 питань визначення напрямів роботи з цього питання;

- запровадження операційного аудиту призвело до подвійного підпорядкування фахівців Рахункової палати, а також відволікання працівників галузевих департаментів на виконання вказаної роботи;

- проведення галузевими підрозділами невластивих їм вузькоспеціалізованих контрольних заходів (зокрема, перевірок державних закупівель) є підгрунтям для реалізації повноважень іншого підрозділу та втрати єдиного напряму аудиту.

6. Кадрові питання.

Недостатній кваліфікаційний рівень спеціалістів, які приймають участь у плануванні ДФА визначається: значною плинністю кадрів; недосконалою системою підвищення кваліфікації фахівців; відсутністю у спеціалістів досвіду роботи, практичних навичок; недостатньою підготовкою кандидатів на посади тощо.

Вплив на стадії формування низової ланки: структура Рахункової палати, галузеві підрозділи в регіонах, КРВ в районах, містах та районах у містах мають обмежену чисельність, при цьому 
їх завантаженість виконанням основних функцій досить значна, відсутні спеціалісти-аналітики, відповідальні за планування ДФА. Вказане призводить до того, що пропозиції до планів зазвичай подаються без попередньо проведеного аналізу.

7. Недосконалість регламентів організації і планування ДФА.

Зміни у законодавстві, якими регулюються повноваження органів ДФА, потребують зміни внутрішньої нормативної бази та інших документів 3 питань взаємовідносин 3 іншими державними органами. Вказане потребує значних витрат людських та часових ресурсів. Крім того, в Службах існують тенденції до зайвої деталізації окремих методологічних питань, що часто створює нормативні суперечності та значно ускладнює виконання поставлених завдань.

8. Людський фактор.

Вказане зумовлено хворобами персоналу, сезонними факторами (відпустки, закінчення звітного періоду) тощо.

9. Неможливість чіткого обрахування робочого часу, необхідного для проведення контрольних заходів.

Вказане пов’язане із значною кількістю централізованих контрольних заходів, до багатьох $з$ яких не визначено конкретні переліки об'єктів, надходженням обов'язкових для виконання позапланових доручень тощо.

10. Невідповідність між поставленими завданнями та ресурсами для їх виконання.

Крім того, є тенденція до невідповідності між поставленими керівництвом завданнями щодо централізованого формування планів (внесення змін), а також ресурсами для їх виконання (часові обмеження, надання доручення щодо виконання завдання лише вузькому колу спеціалістів тощо).

11. Функціональна ізольованість підрозділів планування. 
Згідно з усталеною практикою, підрозділи планування при виконанні поставлених перед ними завдань діють без підтримки юридичних та інших підрозділів, які виконують нормотворчі функції. Вказане призводить до затягування процесу планування (несвоєчасне затвердження планів тощо) та формування планів 3 неналежною якістю.

ІІ. ПОРЯДОК ВИЗНАЧЕННЯ ТЕМАТИК ДЛЯ ДФА ТА ВІДБІР ОБ'ЄКТІВ

12. Відсутність системи аналізу фінансових потоків та діяльності установ і організацій.

Об’єкти аудиту у більшості доводяться вищестоящими державними або правоохоронними органами, а також обираються iз тих, що перевіряються систематично. Крім того, не завжди при відборі об“єктів ДФА враховуються ризики фінансових порушень (вказаний напрямок діяльності в даний час знаходиться у стадії опрацювання).

13. Недостатність необхідної для планування інформації.

Відсутність у органів ДФА та в інших органах (Фонд держмайна тощо) інформації, необхідної для проведення аналізу економічного стану окремих галузей економіки країни, не дозволяє врахувати всі необхідні фактори для ефективної та якісної роботи органів ДФА.

14. Невизначеність мережі об’єктів ДФА.

До вказаного фактору відносяться відсутність чітко визначеної мережі, дріб'язковість включених до неї об'єктів, пересікання 3 мережами підпорядкованих контрольно-ревізійних підрозділів, формування мережі без чітко визначених принципів, часто лише на розсуд галузевих підрозділів. Крім того, невизначеність переліку підконтрольних об'єктів є причиною включення до плану ДФА 
об’єктів, що не належать до компетенції відповідного підрозділу, перевірка яких не забезпечує системності. Вказане стає, зокрема, підгрунтям низької результативності ДФА.

15. Низький безсистемний рівень підготовки сторонніми ініціаторами пропозицій до планів.

Вказане простежується в наданні сторонніми ініціаторами пропозицій щодо проведення ДФА на непідконтрольних об'єктах; здійснення перевірок питань, які вже інспектовано органами ДФА; недостатність обгрунтування необхідності включення контрольних заходів до планів ДФА; надання надлишкової та несистематизованої інформації тощо.

\section{IV. ФОРМУВАННЯ ПРОЕКТУ ПЛАНУ, ЙОГО ПОГОДЖЕННЯ ТА ЗАТВЕРДЖЕННЯ}

16. Низький рівень підготовки проєктів планів.

Низька якість пропозицій до проєкту плану, які подаються структурними підрозділами, неврахування в них вимог законодавчих та нормативно-правових актів призводить до великої кількості зауважень до проєкту плану, на відпрацювання яких відволікаються значні людські та часові ресурси. Неякісний аналіз проєктів призводить до масового виключення заходів аудиту та коригування переліків об'єктів ДФА з початку планового періоду.

17. Порушення процедури планування та низький рівень відповідальності.

Недотримання процедури (зокрема, перенесення керівництвом термінів аудиту окремих етапів планування за ініціативою підрозділів без попереднього погодження з підрозділами організаційної роботи; ініціювання галузевими підрозділами апаратів внесення змін до планів замість підрозділу оргроботи, неподання галузевими підрозділами переліку об'єктів до окремих 
тем контролю тощо) призводить до несвоєчасного затвердження плану, неможливості приступити до виконання планових завдань, зайвої та беззмістовної переписки. Також вказане призводить до затягування формування проєкту плану та затвердження плану, який завідомо потребує внесення змін.

18. Надання переваги зовнішній формі плану над його функціональністю.

На кожному етапі план стає все менш зручним для опрацювання та користування (поєднуються різні тематики, ігноруються конкретні програми, які незалежно від виду та теми контрольного заходу поєднуються за розпорядниками або схожими тематиками). Вказане призводить до зайвих витрат людських та часових ресурсів і може стати причиною недотримання встановлених термінів планування.

Зазначені групи ризиків дозволили сформувати матрицю їх впливу на організацію та методику ДФА, яка потребує відповідної зміни (рис. 7.2).

Згідно з усталеною практикою, ризиком з низьким впливом можуть вважатися питання, які вирішуються в робочому порядку; 3 середнім впливом - які потребують офіційного реагування; 3 високим впливом - проблеми, для вирішення яких необхідно пряме втручання керівних осіб.

В економічні літературі виділяють наступні види засобів контролю.

1.Запобіжні засоби - засоби контролю, створені для запобігання помилкам та недолікам. Зазвичай, є складовою будьяких систем. 


\section{МАТРИЦЯ РИЗИКІВ}

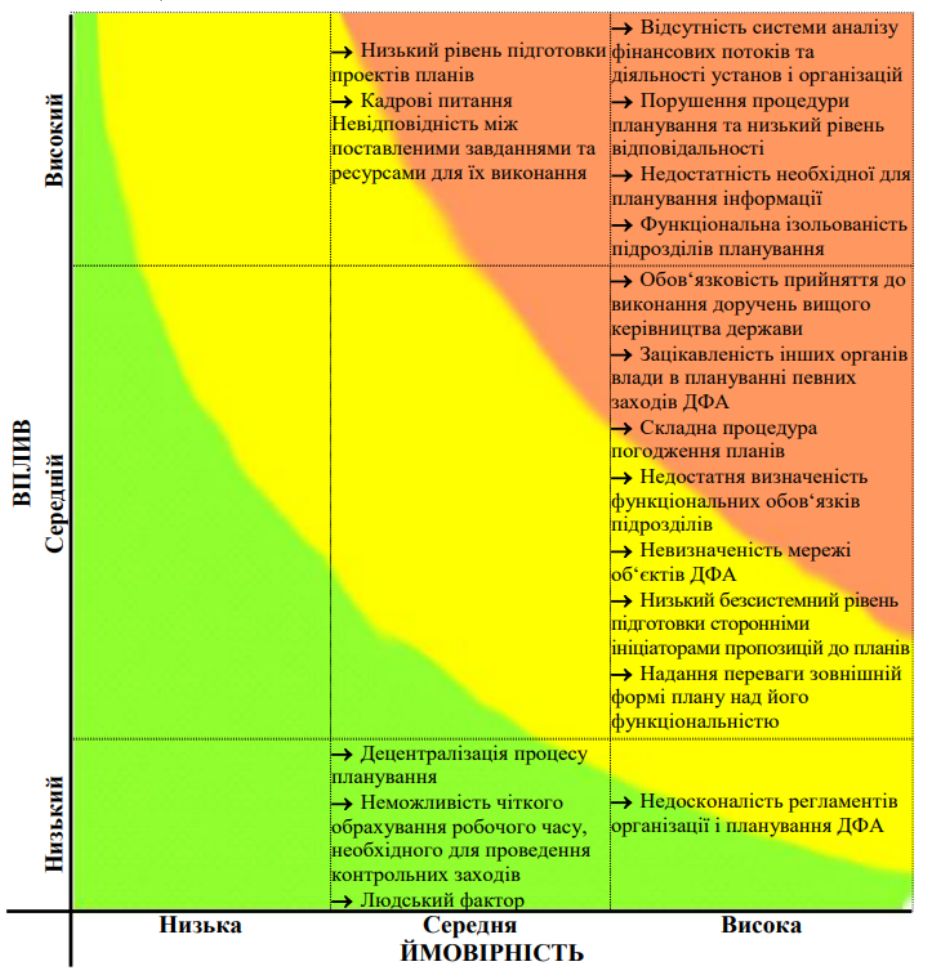

\section{Рис. 7.2. Матриця ризиків}

2.Визначаючі засоби - засоби контролю після здійснення дій, що дозволяють виявити помилки та недоліки.

3.Коригуючи засоби - засоби контролю, які забезпечують виправлення помилок.

4.Відновлюючі засоби - діяльність, що забезпечує виправлення помилок та відшкодування втрат. Всі ці засоби контролю ефективні у комп'ютерному середовищі.

При введенні операції у комп'ютерну систему для запобігання проникнення у неї осіб, які не мають дозволу, використовуються паролі. Якщо запис операції в комп’ютер зроблено некоректно, комп’ютер це помічає та видає сигнал про помилку. Після цього 
оператор отримує інструкцію виправити помилку та шляхом введення правильних даних відновлює операції.

Запобіжні засоби контролю включають в себе:

1) дозвіл на здійснення та власне здійснення операцій;

2) належне документування операцій;

3) своєчасне та належне реєстрування операцій та подій;

4) розподіл обов'язків з метою забезпечення того, щоб на одну особу не припадало виконання усіх складових операцій;

5) обмеження доступу до комп'ютерної системи, підзвітність за ресурси та облікові записи.

В якості прикладів засобів контролю, можна навести:

1. післяопераційні перевірки повноти обробки документів;

2. банківські вивірки;

3. подальший нагляд за виявленими помилками.

Засоби внутрішнього контролю класифікують за типами:

організаційні - здійснюються шляхом розподілу обов’язків, що визначають посадові інструкції;

інформаційні - здійснюються шляхом реалізації концепції політики організації планування, виконання процедур, настанов, директив, використання даних звітності, в тому числі фінансової і системи управлінської інформації;

фізичні - безпека, зберігання/охорона грошових активів;

фінансові - встановлення максимальних розмірів кредитів, бюджетів, використання бухгалтерських рахунків;

управлінські - здійснення нагляду, системи управлінської інформації, мотивація та моральний стан працівників;

процедурні-послідовнийпроцес, щодозволяє відслідковувати роботу системи від початку й до кінця;

незалежні перевірки - зовнішній та внутрішній аудит, 
інспекції, перевірки управлінської діяльності.

У нашому дослідженні ми скористаємося саме цією класифікацією.

У більшості країн державні аудитори спрямовують свою роботу на оцінку загальної відповідності та практичної ефективності існуючих засобів внутрішнього контролю. Оцінка засобів внутрішнього контролю $є$ складовою як аудиторських перевірок, так і аудиту ефективності діяльності.

Як видно з опорної моделі, більшість державних аудиторів:

1) оцінюють систему внутрішнього контролю, тобто контролююче середовище, реєстраційно-інформаційну систему та процеси контролю;

2) перевіряють ефективність системи внутрішнього контролю та визначають критичні моменти в діяльності організації, що підлягають перевірці;

3) готують висновки керівництву, у яких підсумовуються виявлені недоліки та слабкі сторони, та рекомендують заходи для їх виправлення та попередження більш серйозних проблем;

4) проводять відповідні наступні дослідження 3 метою визначення, наскільки адекватно впроваджуються узгоджені 3 керівництвом рекомендації та заходи.

Аудиторові може бути поставлена вимога документувати операції кожного важливою засобу внутрішнього контролю інформаційної системи.

Аудитор має підготувати достатнє документальне обгрунтування для того, щоб чітко описати та проілюструвати систему бухгалтерської звітності; така документація може включати в себе пояснювальні записки та функціональні схеми.

На сьогодні, більшість бухгалтерських операцій на 
підприємствах державного та приватного сектору обробляється комп'ютерами. Отже, належним чином спроєктовані, нормально функціонуючі комп'ютерні системи контролю $є$ невід’ємною складовою будь-якої структури ДФА в цілому.

Міністерства або служби внутрішнього аудиту повинні регулярно перевіряти основні засоби внутрішнього контролю, які мають існувати та діяти у комп’ютеризованому фінансовому середовищі.

Існує чимало засобів контролю, конструктивно передбачених вже в самому використовуваному програмному забезпеченні; інші ж засоби для їхнього використання натомість вимагають виконання процедур за участю людини. Але навіть вбудовані в операційні системи засоби контролю вимагають реагування оператора на повідомлення комп’ютера про помилку чи виявлення невідповідної процедури.

Система засобів внутрішнього контролю призначена для зниження ризиків:

1. Доступу до комп’ютерних даних особам, що не мають відповідного дозволу. Основним принципом для зниження ризиків $\epsilon$ необхідність дотримання режиму спеціальних обмежень, установлених законодавством, перш за все при роботі з таємною інформацією.

2. Здійснення системою недозволених операцій.

3. Неотримання належного дозволу або не завершення обробки операції.

4. Не виявлення та не виправлення виявлених помилок або недоліків.

У переліку контрольних заходів з перевірки, який додається, перелічуються основні засоби контролю, та вимагається від 
відповідального за перевірку поставити такі питання:

1. Чи існують засоби контролю?

2. Якщо вони існують, то чи діють вони на постійній основі?

При виявленні негативних відповідей на ці питання необхідно визначити та оцінити ризики. Можливо існують компенсуючі засоби контролю, що знизять імовірність цих ризиків. Перелік контрольних заходів висвітлює ті основні засоби контролю, які мають існувати та використовуватися для зменшення ризиків:

— Засоби контролю початку операції

— Засоби контролю введення операції

— Засоби контролю обміну даними

— Засоби контролю комп'ютерної обробки інформації

— Засоби контролю зберігання та пошуку даних

— Засоби контролю отримання комп'ютерної інформації

Отже, виходячи з аналізу світового досвіду, викладених нами окремих критеріїв організації державного фінансового аудиту, можна зробити узагальнюючий висновок, що ДФА має двоякий характер: з однієї сторони, це контрольні заходи, які дозволяють оцінити результативність, дієвість та економічність використання організацією, що перевіряється, державних коштів та управління державною власністю за реалізації великих соціально-економічних проєктів із тривалим часовим лагом; 3 іншої - аналіз діяльності органів державної влади щодо виконання ними законів та інших нормативно-правових актів, інструкцій і правил, які визначають порядок витрачання державних коштів, виявлення порушень i відхилень у їх роботі під час реалізації програми.

\section{Методичні прийоми ДФА: елементи верифікації. Із} розвитком системи державного фінансового аудиту однією 3 найважливіших умов упорядкування функціонування державного 
апарату, ефективного використання бюджетних коштів і державної власності, суттєвого покращення соціально-економічного стану у країні, є якісне здійснення контрольної діяльності. Міжнародні стандарти аудиту передбачають, що для підготовки рішення та висновків стосовно об’єкта контролю, служби, програми, виду діяльності чи функції аудитор повинен мати можливість отримувати достатні та відповідні докази.

Результати, висновки та рекомендації аудитора повинні спиратися на докази. 3 огляду на те, що аудитори рідко мають нагоду враховувати всю інформацію про об'єкт контролю, непересічного значення набуває ретельна обробка зібраних даних і техніка відбору необхідних матеріалів. У випадках, коли відомості, що надаються інформаційною системою, відіграють велику роль у перевірці і $\epsilon$ необхідними для досягнення цілей контролю, аудитори обов'язково повинні особисто упевнитися, що такі дані є надійними та доречними.

Аудитори мають добре володіти технікою та процедурами збору доказів: інспекція, спостереження, розслідування та підтвердження.

Визначаючи методи та процедури, слід враховувати якість доказів, тобто вони повинні бути достатніми, доречними і придбаними за розумні кошти.

Аудитори мають збирати в архівах перевірки достатню кількість доказових документів, зокрема у тому, що стосується основи планування, перевірених питань, виконаної роботи та висновків аудиту.

Достатню кількість задокументованих доказів необхідно зібрати для того, щоб:

- підтвердити висновки та звіти аудитора;

- зробити аудит більш ефективним; 
- мати у розпорядженні інформацію, необхідну для підготовки звітів і відповіді на запитання підконтрольного органу (організації) чи будь-якої іншої сторони;

- підтвердити застосування аудитором стандартів аудиту;

- сприяти плануванню та управлінню аудиторською діяльністю;

- сприяти підвищенню професійного рівня аудитора;

- мати можливість упевнитися, що робота, доручена іншим особам, була виконана належним чином;

- зберегти архіви виконаної роботи та мати можливість звертатися до них у подальшому.

Аудитор має пам’ятати, що зміст і формат справи перевірки свідчать про рівень його компетентності, досвід і знання справи. Такі справи повинні бути достатньо повними і детальними для того, щоб досвідчений аудитор міг, не будучи причетним до цього конкретного контрольного заходу, точно встановити для підготовки висновків характер виконаної роботи.

Традиційно, здійснюючи ДФА, аудитори вибирають та застосовують прийоми $і$ процедури, які відповідають конкретним обставинами [4].

Ці прийоми та процедури повинні дозволяти отримувати достатні, дійсні та необхідні докази, які вмотивовано підкріплюють або спростовують їхні точки зору та висновки, зокрема:

- аналіз нормативно-правових актів, планових розрахунків та обгрунтувань, методичних документів, видань і публікацій у сфері реалізації бюджетної програми, стосовно якої проводиться ДФА;

- аналіз результатів раніше здійснених контрольних заходів;

- аналіз показників статистичної, фінансової та оперативної звітності; 
- порівняння фактично досягнутих результативних показників виконання бюджетної програми із запланованими в динаміці за кілька років з вітчизняним і зарубіжним досвідом у сфері реалізації бюджетної програми, з технологічними стандартами тощо;

• інтерв’ювання, анкетування (процес опитування учасників бюджетної програми та користувачів ïi продукту 3 метою встановлення проблемних питань, результати якого фіксуються як письмове одержання інформації від юридичних осіб.

Але інформація, необхідна для проведення ДФА, враховуючи постійну зміну чинного законодавства, вимоги міжнародних стандартів аудиту та складність бюджетного процесу, може бути отримана на основі уніфікованих методичних прийомів.

Так, п.п. 26-38 МСА 500 описують загальні процедури аудиту, які потребують уточнення, адже $є$ не досить коректними для використання в державному секторі економки i повинні використовуватися для отримання і оцінки аудиторських доказів. До них слід віднести:

- інспектування (перевірка);

- спостереження;

- запит;

- підтвердження;

- підрахунок (перерахунок);

- повторне проведення;

- аналітичні процедури.

Наприклад, призначення спостереження полягає в тому, щоб спостерігати, яким чином суб’єкт застосовує процедури і підходи на даний час. Докази, отримані в ході підрахунку, в основному підтверджують існування та вартісну оцінку. Що стосується запитів, 
то однією зі слабких сторін цього методу є те, що вони рідко надають докази, які були б достатніми для підтвердження фактів самі по собі.

Інспектування. Інспектуванню підлягають три види документації:

- документи, підготовлені третіми сторонами і знаходяться у третіх сторін;

- документи, підготовлені третіми сторонами і знаходяться у об'єкта аудиту;

- документи, підготовлені об’єктом аудиту і знаходяться у нього.

До першого виду документів відносяться казначейські/ банківські підтвердження, а також рахунки постачальників; банківські виписки, сплачені чеки, контракти, страхові поліси, договори оренди. Коли документи такого роду бувають отримані безпосередньо від третьої сторони аудитором, вони є надійними доказами щодо стверджень, яких стосуються.

Документи, підготовлені об’єктом аудиту, включають накладні на відвантаження, рахунки на продаж, платіжні доручення, замовлення на придбання тощо. Як правило, інспектування внутрішніх документів об'єкта надає менш достовірні докази, хоча система внутрішнього контролю може суттєво підвищити їх надійність.

Трьома основними способами інспектування у міжнародній практиці є ваучінг, трейсинг та сканування [5].

Принципові відмінності між ними полягають у напрямку тестування. Ваучінг полягає у вивченні документів, які надають докази у підтвердження існування (виникнення та вимірювання), а трейсинг надає докази у підтвердження повноти обліку. Ваучінг використовується для пошуку доказів, які підтверджують значення, 
відображені у обліку. Трейсинг призначений для підтвердження того, що дані фінансової звітності були відповідно відображені в обліку. Прикладом ваучінгу є перевірка рахунків постачальників під час придбання основних засобів. Прикладом трейсингу є перевірка того, що продукція, відображена у журналі відвантаження продукції, була включена до рахунків, виставлених покупцям. Іноді ці способи перевірки є взаємовиключними. Для перевірки існування і повноти потрібно виконувати різні тести, тому що первинні документи для кожного тесту напряму тестування не можуть бути однаковими.

Крім інспектування документів, аудитори можуть інспектувати матеріальні активи, грошові кошти, товарноматеріальні запаси та основні засоби з метою підтвердження їх існування.

Спостереження. Застосовується, як правило, для того, щоб оцінити виконання на практиці процедури внутрішнього контролю належним чином. Аудитори звичайно спостерігають за діями інвентаризаційних комісій стосовно дотримання чинних вимог. Проте ризиковано стверджувати, що процедури, виконані під наглядом, таким саме чином виконуються без нього. Це стосується будь-яких процесів.

Повторне проведення. Аудитор може повторно провести незалежним чином процедури або контрольні заходи, які первісно були здійснені як складник системи внутрішнього контролю об'єкту аудиту. Повторне проведення можливе вручну або за допомогою комп’ютерних засобів аудиту.

Запит. Є пошуком інформації у осіб всередині або поза об’єктом аудиту, які мають інформацію. Застосовується протягом усього процесу аудиту, починаючи з попереднього обговорення $\mathrm{i}$ закінчуючи завершенням аудиту. Вважається достатньо слабким 
доказом 3 боку. Усні докази завжди повинні підкріплюватися іншою інформацією, а найбільш важливі докази мають надаватися аудиторам у письмовому вигляді. Проте, якщо надана за різними джерелами інформацій внаслідок запитів не суперечить одна одній, то це вважається свідченням з високою надійністю.

Підтвердження. Підтвердження $є$ методом отримання доказів від третіх сторін відносно конкретних сальдо, умов угод i договорів, права власності на активи та можливих позовів. Основними твердженнями, стосовно яких отримуються докази 3 допомогою зовнішніх підтверджень, є існування і право власності, але це може бути і повнота, якщо зовнішні докази стосуються інформації про зобов'язання (наприклад, відносно кредиторської заборгованості). Зовнішні підтвердження застосовуються для сальдо за поточними рахунками, дебіторської заборгованості, товарноматеріальних запасах, які знаходяться у розпорядженні третіх осіб, за незакінченими судовими процесами, за позиками тощо.

Рекомендації з отримання доказів щодо дебіторів, знаходяться у MCA 505. Сутність позитивного підтвердження полягає у тому, що дебітор перешле підтвердження аудитору з зазначенням сальдо за взаємними розрахунками навіть у тих випадках, якщо відповідна сума правильно вказана у запиті на підтвердження. Така форма надає більш надійні докази, оскільки аудитор контролює ситуацію у випадках, коли не отримана відповідь, та застосовують у таких випадках додаткові процедури. При негативних підтвердженнях, коли дебіторів просять відповісти аудитору тільки у випадках, коли вказані у запиті сальдо не узгоджуються з бухгалтерськими записами дебітора, аудитор не може контролювати ситуацію, оскільки не знає, чи означає мовчання згоду чи відсутність відповіді.

Підрахунок. Являє собою перевірку арифметичної точності 
первинних документів або бухгалтерських записів, а також проведення незалежних підрахунків. Аудитори можуть підрахувати знос та порівняти його суми з відображеними в обліку або перевірити точність визначення вартості товарно-матеріальних запасів на звітну дату. Останнім часом розрахунки такого призначення виконуються програмним забезпеченням об'єкта аудиту. Аудитор може використати власні комп'ютерні програми для перевірки розрахунків та виявлення розбіжностей, з приводу яких можна проводити подальше розслідування.

Аналітичні процедури. Аналіз полягає у розрахунку коефіцієнтів та ілюстрації тенденцій, які мають важливе значення (як правило, шляхом порівняння, наприклад, 3 попередніми періодами, 3 кошторисом, 3 галузевою інформацією тощо) i дослідження відхилень та взаємозв'язків, які не узгоджуються 3 іншою доцільною інформацією або очікуваннями (прогнозами). Застосування аналітичних процедур викладено в МСА 520. Аналітичні процедури широко використовуються аудиторами, тому що є ефективним інструментом для виявлення суттєвих відхилень, крім того, вони простіші і дешевші порівняно з іншими процедурами аудиту. Як вказано у п. 2 МСА 520, аналітичні процедури можуть застосовуватись на різних стадіях аудиту:

- під час планування, щоб оцінити ризик і визначити характер, час та обсяг аудиторських процедур, які слід застосувати;

- під час виконання аудиту, щоб надати аудиторські докази на підтвердження конкретних тверджень;

- під час завершення аудиту, щоб оцінити загальне подання фінансової звітності.

Застосування аналітичних процедур на стадії планування і на оглядовій стадії аудиту вимагається п. 2 МСА 520. Аудитор може 
застосувати конкретні ствердження, якщо аудитор має підстави вважати, що їх застосування підвищить результативність та ефективність аудиту.

Коли аналіз використовується для надання аудиторських доказів, які підтверджують ствердження (існування, повноти, оцінки, розкриття тощо), аудитор повинен переконатися, що характер аудиторських процедур відповідає рівню бажаної впевненості. Фактором, яким визначає рішення аудитора, є те, чи буде аналіз використовуватися як головний або єдиний доказ (первинний доказ) чи в якості додаткового доказу. Звичайно, у першому випадку результати повинні надавати більш високий рівень впевненості, ніж тоді, коли аналіз використовується одночасно 3 іншими процедурами. Таким чином, обираючи аналіз у якості способу отримання аудиторських доказів, аудитор зобов'язаний вчинити таке:

- оцінити, чи дозволяє існування змістовних взаємовідносин між даними підготувати обгрунтовані аудиторські очікування (наприклад, щодо надходжень за видами податків до державного бюджету);

- визначити, чи рівень надійності, який нададуть докази, отримані в результаті аналізу, буде відповідати цілям аудиту.

Залежно від змісту процедури i форми отримання аудиторських доказів, їх доцільно класифікувати на матеріальні, усні, документальні та аналітичні.

Матеріальні докази одержують при спостереженні за якимись подіями або діями людей, а також при перевірці майна. Вони можуть бути представленні у формі фотографій, схем, карт, графіків або в іншому графічному вигляді. Слід мати на увазі, що зображення ситуації на фотографії або схемі є набагато переконливішим доказом, 
ніж іiі письмовий опис.

У випадках, коли докази, одержані в результаті спостереження за подією або перевірки майна, вкрай важливі для досягнення цілей аудиту ефективності, спостереження доцільно проводити за участю не менше двох членів групи перевіряючих i, за можливості, представника організації, що перевіряється.

Усні докази можуть бути одержані в результаті спілкування членів групи перевіряючих 3 керівництвом i співробітниками організацій, що перевіряються, та вищестоящих організацій, зовнішніми експертами, а також проведення відповідних опитувань та інтерв’ю. Усні докази, як правило, повинні використовуватися як початкова інформація для отримання інших доказів.

Якщо в процесі бесід, опитувань або інтерв’ю одержано цінну усну інформацію, яку можна використати як аудиторський доказ, треба одержати іï письмове підтвердження від особи, яка повідомила дану інформацію. Разом 3 цим, для іiі додаткового підтвердження доцільно використовувати інші різні джерела, порівнюючи їх інформацію з одержаною усною інформацією. Крім того, для підтвердження даної інформації може бути проведена перевірка відповідної документації.

Документальні докази є найпоширенішою формою аудиторського доказу і можуть бути представлені на паперових носіях або в електронному вигляді. Вони можуть бути як внутрішніми, одержаними в організації, що перевіряється, так i зовнішніми, одержаними за їі межами.

Внутрішні документальні докази можна одержати на основі фінансової документації, що є в організації, що перевіряється, копій вихідних і вхідних документів, наказів і розпоряджень, планів i звітів про роботу, положень і посадових інструкцій та інших 
документів. При цьому слід мати на увазі, що сам факт наявності в організації, що перевіряється, тих або інших документів, ще не означає можливість їх використання як документальних доказів. Кожен документ треба розглядати, перш за все, в контексті цілей аудиту ефективності та відносно вибраних критеріїв оцінки ефективності.

Наприклад, наявність якогось внутрішнього положення, інструкції або керівництва не $є$ доказом того, що вони використовуються в діяльності організації. Тому треба з'ясувати, які результати застосування даних документів. Крім того, необхідно провести аналіз документів, що відображають результати функціонування систем управлінської інформації та контролю (наприклад, системи бухгалтерського обліку). При цьому бажано, щоб рішення щодо використання цих документів перевіряючі приймали як докази тільки на основі аналізу системи внутрішнього контролю, яка діє в організації, що перевіряється, і відповідної оцінки якості їі функціонування.

Зовнішні документальні докази можуть бути одержані на основі документів, які підготовлені вищестоящими й іншими організаціями та мають безпосереднє відношення до діяльності організації, що перевіряється. Вони можуть включати листи i службові записки, одержані організацією, що перевіряється, рахунки від постачальників, договори оренди, контракти, звіти про результати аудиторських перевірок, підтверджуюча документація, одержана від третіх осіб тощо.

Аналітичні докази можуть бути одержані в результаті аналізу окремих показників, їх сукупності або різних даних про діяльність організації, що перевіряється. Необхідна для цього інформація може бути одержана як в організації, що перевіряється, так і з інших 
джерел.

Як аналітичні докази можуть використовуватися розрахунки відносних показників діяльності організації, що перевіряється, та їх порівняння із встановленими стандартами або галузевими нормативами. Наприклад, це можуть бути розрахунки показника продуктивності діяльності організації, що перевіряється, співвідношення між досягнутими нею результатами (обсягом виробленої продукції або наданих послуг) і витраченими ресурсами (матеріальними, фінансовими, трудовими).

Аналітичні докази можуть бути одержані на основі виявлення й аналізу тих або інших тенденцій або проблем в діяльності організації, що перевіряється. Наприклад, таких, як висока плинність кадрів, велика кількість претензій та скарг на організацію, що перевіряється, з боку споживачів їі продукції або послуг.

Процес збору інформації та фактичних даних для отримання аудиторських доказів включає наступні етапи:

1) аудитори збирають інформацію відповідно до програми проведення аудиту, перевіряють їі повноту, прийнятність і достовірність;

2) аналізують зібрані фактичні дані та визначають, чи є вони достатніми для того, щоб оцінити роботу об’єкта аудиту на основі використаних критеріїв;

3) якщо цієї інформації не достатньо, збираються додаткові дані.

Джерелами інформації для отримання аудиторських доказів $€$ :

- чинне законодавство та нормативно-правові акти, які регулюють діяльність бюджетної сфери та організації, що 
перевіряється;

- планові дані за затвердженим бюджетом на черговий фінансовий рік, за якими можна одержати фінансову й іншу інформацію про діяльність бюджетної сфери чи організації, що перевіряється;

- опитування й інтерв’ю 3 компетентними особами за умови, що отримана інформація повинна підтверджуватися з інших джерел. До інтерв’ю необхідно добре підготуватися. Для цього бажано заздалегідь скласти список питань i, в деяких випадках, доцільно передати його особі, в якої братиметься інтерв'ю. Важливість інтерв’ю полягає у тому, що в процесі його проведення можна одержати певні підказки, на що слід звернути особливу увагу і де можна знайти найдокладнішу інформацію про діяльність організації, що перевіряється, для підтвердження результатів аудиту ефективності;

- документи на паперових носіях або в електронному вигляді, що стосуються різних сторін діяльності організації, що перевіряється, таких, як планування, організація внутрішнього контролю, проведення колегій і нарад, розгляд скарг і вирішення суперечок, результатів аудиторських перевірок тощо;

- внутрішня звітність і аналітичні огляди організації, що перевіряється, в яких узагальнюється інформація для керівництва або пропонуються заходи щодо усунення недоліків у роботі. Аудитори повинні знайти і провести аналіз таких звітів та оглядів, використовуючи для цього, зокрема, інтерв'ю із співробітниками організації, що перевіряється, та матеріали протоколів колегій i нарад керівництва;

- бази даних організації, що перевіряється, в яких накопичується відповідна інформація, що стосується іiі діяльності. 
Одержана на їх основі інформація може бути важливим джерелом аудиторського доказу, особливо при кількісній оцінці показників їі діяльності;

- зовнішні джерела інформації, до яких належать великі спеціалізовані бібліотеки, що мають літературу з питань сфери діяльності організації, що перевіряється;

- результати попередніх аудитів.

Вочевидь, що використовувати одночасно всі перераховані джерела інформації і фактичних даних для отримання аудиторських доказів і вивчити всі відповідні документи практично неможливо, оскільки це потребує значно більших витрат часу, ніж звичайно має у своєму розпорядженні на збір інформації група аудиторів. Тому, при вирішенні питань щодо джерел зібраної інформації і обсягів вивчення документів, члени групи аудиторів повинні керуватися своїми професійними міркуваннями, використовуючи ті або інші методи їх вибірки з урахуванням цілей аудиту та критеріїв оцінки ефективності.

В процесі збору фактичних даних аудитори повинні враховувати, що не всяка інформація може бути використана як аудиторський доказ. Це, наприклад, такі випадки, коли:

- інформація одержана лише 3 одного джерела (це може вплинути на надійність, достовірність і достатність доказу);

- усна інформація не підтверджується документами або іншими джерелами (вплив на надійність);

- інформація характеризує минуле, тобто вона застаріла і не відображає змін, що відбулися (вплив на релевантність);

- витрати на отримання інформації дуже великі відносно можливих результатів іï використання (вплив на релевантність і достатність); 
- джерело інформації має зацікавленість щодо результатів іiі використання (вплив на достовірність);

- зроблена вибірка інформації не репрезентативна (вплив на релевантність, обгрунтованість, достатність);

- інформація відноситься до одиничного випадку (вплив на обгрунтованість і достатність);

- інформація є неповною, тобто не відображає причину або наслідок факту або події (вплив на достовірність і достатність);

- інформація за своїм змістом є вельми суперечливою (вплив на достовірність).

Під час збору інформації члени групи аудиторів повинні використовувати фактичні дані та результати роботи внутрішнього контролю об'єктів аудиту, а також інших фахівців щодо оцінки ефективності тієї або іншої програми, сфери або напряму діяльності організації, що перевіряється, якщо вони можуть бути застосовані до цілей проведення даного аудиту і критеріїв оцінки ефективності. Це сприяє економії часу та коштів перевіряючих у результаті усунення дублювання.

Якщо в процесі збору інформації та фактичних даних група аудиторів зіткнулася 3 непередбаченими труднощами, що виникли відносно якості наявних даних або доступу до необхідної інформації, здійснюється перегляд методів i порядку проведення аудиту. Процес збору фактичних даних повинен бути організований так, щоб висновки за результатами аудиту, зроблені на основі зібраних доказів, були здатні витримати будь-який критичний аналіз.

Державні аудитори застосовують системний підхід та використовують тестування для оцінки ступеня відповідності діяльності організації (установи, програми) вимогам законодавчих та нормативних актів, а також ефективності та доцільності управління 
нею [6].

На предмет відповідності в системі ДФА доцільно протестувати:

1.Засоби контролю, що забезпечують відповідність найважливішим вимогам законодавчих та нормативних актів, в тому числі у бюджетній сфері.

2.Засоби операційного аудиту по кожній важливій операції.

3.Засоби контролю фінансової звітності за кожним вагомим бухгалтерським записом.

У методиці ДФА, якщо засіб контролю розроблений невідповідним чином та не введений у дію, сенсу тестувати його немає. При цьому аудитор просто повідомляє про відсутність такого засобу контролю та про існування ризику виникнення збитків.

Якщо ж засоби контролю існують та діють, аудитор проводить таке тестування їхньої ефективності, яке є достатнім для того, щоб дійти висновку, що ризик відмови цих засобів контролю є низьким.

В аудиті економічних систем аудиторів повинні цікавити характеристики системи, а не суми грошових коштів, що проходять крізь них.

Тести можуть застосовуватися на трьох стадіях аудиту.

На стадії планування, на якій доцільно використовувати короткі тести (вибірка одного або двох показників) для визначення існування засобів контролю на рівнях їх розробки.

На стадії оцінки, на якій доцільно використовувати тести для підтвердження реальної дії засобів контролю.

На стадії верифікації більш детально тестуємо ті засоби контролю, які є дуже важливими, або ті, що під час початкової оцінки були визначені як слабкі й такі, що несуть ризики.

Перед виконанням основних тестів засобів контролю 
аудитор здійснює короткі «побіжні» тести з тим, аби визначити, чи контролююча діяльність:

1) дійсно існує; та

2) функціонує у зрозумілий аудиторові спосіб.

Ці «побіжні» тести призначені для того, аби підтвердити розуміння аудитором контролюючої діяльності, й відтак, відрізняються від тестів, що виконуються для підтвердження розуміння аудитором тих систем, у яких ці засоби контролю використовуються.

Використовуючи результати спостережень, перевірок та обговорень 3 працівниками, відповідальними за застосування та підтримку кожного засобу контролю та тестування, аудитор може визначити, чи дійсно кожен засіб контролю практично застосовується.

Якщо якийсь засіб контролю не застосовується, аудитор має розглянути імовірність досягнення цілій аудиту за допомогою інших засобів контролю, а також можливість тестування таких засобів контролю.

Тести можуть проводитися:

1) у вигляді спостережень за працівниками, що займаються контролюючою діяльністю в рамках своїх звичайних службових обов'язків;

2) у вигляді письмових чи усних запитів на адресу працівників, які беруть участь у застосуванні конкретних елементів системи контролю;

3) у вигляді інспектування, яке, як правило, вимагає ознайомлення 3 документами, які стосуються системи контролю.

Спостереження, як різновид тесту, є кращим за запит, а запит - кращим за інспекцію. 
Результати дослідження засвідчили, що процес тестування найдоцільніше розподіляється на сім етапів:

Eman 1. Визначити мету тестування.

У державному фінансовому аудиті для отримання доказів існування та використання засобів контролю використовується аудиторська вибірка.

Eman 2. Визначити сукупність та одиниці вибірки.

Сукупність (тобто, той масив даних, 3 яких вибирається елемент вибірки) походить безпосередньо з визначення мети тесту.

Одиниці вибірки, як правило, визначаються як окремі елементи, 3 яких складається ціле (сукупність) (вони можуть складатися з документів, окремих записів, статей (позицій) чи інших елементів).

Eman 3. Визначити умови виключень.

Дати визначення помилок, порушень та відхилень.

Eman 4. Визначити чисельність вибірки.

1. Чисельність вибірки має збільшуватися одночасно зі зростанням важливості тесту.

2. Чисельність вибірки має збільшуватися одночасно із збільшенням очікуваної кількості помилок у сукупності.

Eman 5. Визначити метод вибору елементів вибірки.

Елементи вибірки мають вибиратися таким чином, щоб вибірка була репрезентативною. Можливі наступні варіанти.

1. Імовірнісний /статистичний відбір.

2. Суб'єктивна репрезентативна вибірка.

Eman 6. Завершити аудиторський тест.

Eman 7. Проаналізувати отримані результати:

1.Здійснити проекцію результатів вибірки на сукупність.

2.Проаналізувати походження виявлених помилок: 
а) чи є вони поодинокими або систематичними?

б) якими є причини їхньої появи та які наслідки вони спричинили?

в) чи є необхідність у проведенні подальших тестів?

Етап 3 може висвітлити певні недоліки у засобах контролю або інші невідповідності. На Етапі 4 нам може знадобитися визначити можливі масштаби та природу недоліків. При цьому процес тестування буде таким самим, що й на Етапі 3, за виключенням того, що нам доведеться звузити мету тесту та збільшити чисельність вибірки.

Наприклад, якщо у наведеному вище прикладі із виплатою заробітної платні (з тестовою вибіркою 20 одиниць) виявиться, що у чотирьох випадках підвищення заробітної платні не було дозволено, то на Етапі 4 доведеться розширити чисельність вибірки для тесту лише по цьому параметру, скажімо, до 50. Це дасть доказ для підтвердження висновку.

Це дає підстави розглядати характер вибірки в аудиті і ii використання в процесах тестування внутрішнього контролю й аудиторської перевірки на основі вартісної оцінки.

Аудитор використовує вибірку через те, що дуже рідко надається можливість одержання абсолютної впевненості про генеральну сукупність, підданої аудитові. До того ж, дослідження окремої операції або елемента, що становлять одну статтю в Бюджеті, економічно неефективно.

Статистичний метод вибіркової перевірки, особливо в частині бюджетних видатків і доходів, будується на використанні теорії ймовірностей для побудови вибірки з генеральної сукупності і їі оцінки з метою складання висновку про сукупність в цілому.

Переваги статистичного методу вибіркової перевірки 
полягають в достатності відомостей про аудиторський ризик. Цей метод вимагає точного й певного підходу до аудиторської проблеми. Перевагою нестатистичного методу вибіркової перевірки $€$ можливість для аудитора більш вільно використати професійне судження.

Статистичний метод вибірки використається, коли випадкові числа можуть бути співвіднесені 3 елементами генеральної сукупності й коли об'єктивний виправданий результат бажаний. Нестатистичний метод вибіркової перевірки може використовуватися в умовах, коли аудитор має додаткові відомості про генеральну сукупність, коли об’ єктивний виправданий результат не потрібен, і коли співвіднесення випадкових чисел ускладнено або неможливо.

Розмір вибірки змінюється прямолінійно 3 очікуваним коефіцієнтом відхилень у генеральній сукупності й розміром генеральної сукупності. Розмір вибірки змінюється у зворотній залежності із припустимим ризиком надмірної довіри й припустимим коефіцієнтом відхилень. Вплив розміру генеральної сукупності мінімальний, за винятком щодо малих генеральних сукупностей. Для доведення висунутих гіпотез сформовано наступні таблиці оцінки статистичної вибірки (табл. 7.6-7.10).

Таблиияя 7.6

Оцінка результатів статистичної вибірки для тестів контролю

Верхня межа відхилення (сукупність 5000 одиниць)

5\% - ризик оцінки ризику контролю є дуже низьким

Розмір вибірки /Фактична кількість знайдених відхилень

\begin{tabular}{|c|c|c|c|c|c|c|c|c|c|}
\hline & 0 & 1 & 2 & 3 & 4 & 5 & 6 & 7 & 8 \\
\hline 25 & 11.3 & 17.6 & $*$ & $*$ & $*$ & $*$ & $*$ & $*$ & $*$ \\
\hline 30 & 9.5 & 14.9 & 19.5 & $*$ & $*$ & $*$ & $*$ & $*$ & $*$ \\
\hline
\end{tabular}


Продовження таблиияі 7.6

\begin{tabular}{|c|c|c|c|c|c|c|c|c|c|}
\hline 35 & 8.2 & 12.9 & 16.9 & $*$ & $*$ & $*$ & $*$ & $*$ & $*$ \\
\hline 40 & 7.2 & 11.3 & 14.9 & 18.3 & $*$ & $*$ & $*$ & $*$ & $*$ \\
\hline 45 & 6.4 & 10.1 & 13.3 & 16.3 & 19.2 & $*$ & $*$ & $*$ & $*$ \\
\hline 50 & 5.8 & 9.1 & 12.1 & 14.8 & 17.4 & 19.9 & $*$ & $*$ & $*$ \\
\hline 55 & 5.3 & 8.3 & 11.0 & 13.5 & 15.9 & 18.1 & $*$ & $*$ & $*$ \\
\hline 60 & 4.9 & 7.7 & 10.1 & 12.4 & 14.6 & 16.7 & 18.8 & $*$ & $*$ \\
\hline 65 & 4.5 & 7.1 & 9.4 & 11.5 & 13.5 & 15.5 & 17.4 & 19.3 & $*$ \\
\hline 70 & 4.2 & 6.6 & 8.7 & 10.7 & 12.6 & 14.4 & 16.2 & 18.0 & 19.7 \\
\hline 75 & 3.9 & 6.2 & 8.2 & 10.0 & 11.8 & 13.5 & 15.2 & 16.9 & 18.4 \\
\hline 80 & 3.7 & 5.8 & 7.7 & 9.4 & 11.1 & 12.7 & 14.3 & 15.8 & 17.3 \\
\hline 90 & 3.3 & 5.2 & 6.8 & 8.4 & 9.9 & 11.3 & 12.7 & 14.1 & 15.5 \\
\hline 100 & 3.0 & 4.7 & 6.2 & 7.6 & 8.9 & 10.2 & 11.5 & 12.7 & 14.0 \\
\hline 125 & 2.4 & 3.7 & 4.9 & 6.1 & 7.2 & 8.2 & 9.3 & 10.3 & 11.3 \\
\hline 150 & 2.0 & 3.1 & 4.1 & 5.1 & 6.0 & 6.9 & 7.7 & 8.6 & 9.4 \\
\hline 200 & 1.5 & 2.3 & 3.1 & 3.8 & 4.5 & 5.2 & 5.8 & 6.5 & 7.1 \\
\hline
\end{tabular}

$10 \%$ - ризик оцінки контролю є дуже низьким

Розмір вибірки /Фактична кількість знайдених відхилень

\begin{tabular}{|c|c|c|c|c|c|c|c|c|c|}
\hline & 0 & 1 & 2 & 3 & 4 & 5 & 6 & 7 & 8 \\
\hline 20 & 10.9 & 18.1 & $*$ & $*$ & $*$ & $*$ & $*$ & $*$ & $*$ \\
\hline 25 & 8.8 & 14.7 & 19.9 & $*$ & $*$ & $*$ & $*$ & $*$ & $*$ \\
\hline 30 & 7.4 & 12.4 & 16.8 & $*$ & $*$ & $*$ & $*$ & $*$ & $*$ \\
\hline 35 & 6.4 & 10.7 & 14.5 & 18.1 & $*$ & $*$ & $*$ & $*$ & $*$ \\
\hline 40 & 5.6 & 9.4 & 12.8 & 15.9 & 19.0 & $*$ & $*$ & $*$ & $*$ \\
\hline 45 & 5.0 & 8.4 & 11.4 & 14.2 & 17.0 & 19.6 & $*$ & $*$ & $*$ \\
\hline 50 & 4.5 & 7.6 & 10.3 & 12.9 & 15.4 & 17.8 & $*$ & $*$ & $*$ \\
\hline 55 & 4.1 & 6.9 & 9.4 & 11.7 & 14.0 & 16.2 & 18.4 & $*$ & $*$ \\
\hline 60 & 3.8 & 6.3 & 8.6 & 10.8 & 12.9 & 14.9 & 16.9 & 17.9 & $*$ \\
\hline 70 & 3.2 & 5.4 & 7.4 & 9.3 & 11.1 & 12.8 & 14.6 & 16.2 & 17.9 \\
\hline 80 & 2.8 & 4.8 & 6.5 & 8.3 & 9.7 & 11.3 & 12.8 & 14.3 & 15.7 \\
\hline 90 & 2.5 & 4.3 & 5.8 & 7.3 & 8.7 & 10.1 & 11.4 & 12.7 & 14.0 \\
\hline 100 & 2.3 & 3.8 & 5.2 & 6.6 & 7.8 & 9.1 & 10.3 & 11.5 & 12.7 \\
\hline 120 & 1.9 & 3.2 & 4.4 & 5.5 & 6.6 & 7.6 & 8.6 & 9.6 & 10.6 \\
\hline 160 & 1.4 & 2.4 & 3.3 & 4.1 & 4.9 & 5.7 & 6.5 & 7.2 & 8.0 \\
\hline 200 & 1.1 & 1.9 & 2.6 & 3.3 & 4.0 & 4.6 & 5.2 & 5.8 & 6.4 \\
\hline
\end{tabular}




\section{Оцінка розміру вибірки}

Розміри статистичної вибірки для тестів контролю (сукупність 5000 одиниць)

5\% - ризик оцінки ризику контролю є дуже низьким

\begin{tabular}{|c|c|c|c|c|c|c|c|c|c|c|}
\hline & \multicolumn{10}{|c|}{ Припустима норма відхилення } \\
\hline & & $2 \%$ & $3 \%$ & $4 \%$ & $5 \%$ & $6^{0}$ & $7 \%$ & $8 \%$ & $9 \%$ & $10 \%$ \\
\hline 0.00 & & 49 & 99 & 74 & 59 & 4 & 42 & 36 & 32 & 29 \\
\hline 0.50 & & * & 157 & 117 & 93 & $7 \varepsilon$ & 66 & 58 & 51 & 46 \\
\hline 1.00 & & * & $*$ & 156 & 93 & $7 \varepsilon$ & 66 & 58 & 51 & 46 \\
\hline 1.50 & & * & * & 192 & 124 & 10 & 66 & 58 & 51 & 46 \\
\hline 2.00 & & * & * & * & 181 & 12 & 88 & 77 & 68 & 46 \\
\hline 2.50 & & * & * & $*$ & * & 15 & 109 & 77 & 68 & 61 \\
\hline 3.00 & & $*$ & * & $*$ & $*$ & 19 & 129 & 95 & 84 & 61 \\
\hline 4.00 & & $\%$ & * & $*$ & * & * & * & 146 & 100 & 89 \\
\hline 5.00 & & * & * & * & * & * & * & * & 158 & 116 \\
\hline 6.00 & & * & * & & * & * & * & * & * & 179 \\
\hline \multicolumn{11}{|c|}{ 10\% - Ризик оцінки контролю є дуже низьким } \\
\hline \multirow{2}{*}{\multicolumn{2}{|c|}{$\begin{array}{l}\text { Очікуване } \\
\text { відхилення } \\
\text { сукупності } \\
\text { (норма \%) }\end{array}$}} & \multicolumn{6}{|c|}{ Припустима норма відхилення } & & & \\
\hline & & $2 \%$ & $3 \%$ & $4 \%$ & $5 \%$ & $6 \%$ & $7 \%$ & $8 \%$ & $9 \%$ & $10 \%$ \\
\hline 0.00 & & 114 & 76 & 57 & 45 & 38 & 32 & 28 & 25 & 22 \\
\hline 0.50 & & 194 & 129 & 96 & 77 & 64 & 55 & 48 & 42 & 38 \\
\hline 1.00 & & * & 176 & 96 & 77 & 64 & 55 & 48 & 42 & 38 \\
\hline 1.50 & & * & * & 132 & 105 & 64 & 55 & 48 & 42 & 38 \\
\hline 2.00 & & * & * & 198 & 132 & 88 & 75 & 48 & 42 & 38 \\
\hline 2.50 & & $*$ & * & * & 158 & 110 & 75 & 65 & 58 & 52 \\
\hline 3.00 & & $*$ & * & * & * & 132 & 94 & 65 & 58 & 52 \\
\hline 4.00 & & $*$ & * & * & * & * & 149 & 98 & 73 & 65 \\
\hline 5.00 & & $*$ & * & * & * & * & * & 160 & 115 & 78 \\
\hline 6.00 & & $*$ & * & $*$ & $*$ & $*$ & * & $*$ & 182 & 116 \\
\hline
\end{tabular}

* Розмір вибірки є достатньо більшим для того, щоб бути ефективними з погляду витрат

Таблиия 7.8

Фактори надійності для оцінки результатів вибірки по методу ймовірності пропорційно розміру

\begin{tabular}{|c|c|c|c|c|c|c|c|c|c|}
\hline $\begin{array}{c}\text { Кількість } \\
\text { перебільшень }\end{array}$ & $1 \%$ & $5 \%$ & $10 \%$ & $15 \%$ & $20 \%$ & $25 \%$ & $30 \%$ & $37 \%$ & $50 \%$ \\
\hline 0 & 4.61 & 3.00 & 2.31 & 1.90 & 1.61 & 1.39 & 1.21 & 1.00 & 0.70 \\
\hline 1 & 6.64 & 4.75 & 3.89 & 3.38 & 3.00 & 2.70 & 2.44 & 2.14 & 1.68 \\
\hline
\end{tabular}


Продовження таблиці 7.8

\begin{tabular}{|c|c|c|c|c|c|c|c|c|c|}
\hline 2 & 8.41 & 6.30 & 5.33 & 4.72 & 4.28 & 3.93 & 3.62 & 3.25 & 2.68 \\
\hline 3 & 10.05 & 7.76 & 6.69 & 6.02 & 5.52 & 5.11 & 4.77 & 4.34 & 3.68 \\
\hline 4 & 11.61 & 9.16 & 8.00 & 7.27 & 6.73 & 6.28 & 5.90 & 5.43 & 4.68 \\
\hline 5 & 13.11 & 10.52 & 9.28 & 8.50 & 7.91 & 7.43 & 7.01 & 6.49 & 5.68 \\
\hline 6 & 14.57 & 11.85 & 10.54 & 9.71 & 9.08 & 8.56 & 8.12 & 7.56 & 6.67 \\
\hline 7 & 16.00 & 13.15 & 11.78 & 10.90 & 10.24 & 9.69 & 9.21 & 8.63 & 7.67 \\
\hline 8 & 17.41 & 14.44 & 13.00 & 12.08 & 11.38 & 10.81 & 10.31 & 9.68 & 8.67 \\
\hline 9 & 18.79 & 15.71 & 14.21 & 13.25 & 12.52 & 11.92 & 11.39 & 10.74 & 9.67 \\
\hline 10 & 20.15 & 16.97 & 15.41 & 14.42 & 13.66 & 13.02 & 12.47 & 11.79 & 10.67 \\
\hline
\end{tabular}

Фактори надійності відносно перебільшень/ Ризик неправильного прийняття пердставлені у таблиці 7.8

Розширення факторів для вибірки за методом ймовірності пропорційно розміру передбачає наступну послідовність і сформовану таблицю 7.9.

Розширення факторів відносно прогнозованих перекручень.

Ризик неправильного прийняття 1\% 5\% 10\% 15\% 20\% 25\% 30\% 37\% 50\%

Фактор розширення 1.91 .61 .51 .41 .31 .251 .21 .151 .0

Таблиияя 7.9

\section{Співвідношення бажаного виправлення з урахуванням ризику}

вибірки й припустимого перекручування

\begin{tabular}{|c|c|c|c|c|}
\hline \multirow{2}{*}{$\begin{array}{c}\text { Ризик } \\
\text { непавильного } \\
\text { прийняття }\end{array}$} & $\underline{4}$ Ризик неправильної відмови \\
\cline { 2 - 5 } & $\underline{0.20}$ & $\underline{0.10}$ & $\underline{0.05}$ & $\underline{0.01}$ \\
\hline 0.01 & 0.355 & 0.413 & 0.457 & 0.525 \\
\hline 0.025 & 0.395 & 0.456 & 0.500 & 0.568 \\
\hline 0.05 & 0.437 & 0.300 & 0.543 & 0.609 \\
\hline 0.075 & 0.471 & 0.532 & 0.576 & 0.641 \\
\hline 0.10 & 0.500 & 0.561 & 0.605 & 0.668 \\
\hline 0.15 & 0.511 & 0.612 & 0.653 & 0.712 \\
\hline 0.20 & 0.603 & 0.661 & 0.700 & 0.753 \\
\hline 0.25 & 0.653 & 0.708 & 0.742 & 0.791 \\
\hline 0.30 & 0.707 & 0.756 & 0.787 & 0.829 \\
\hline 0.35 & 0.766 & 0.808 & 0.834 & 0.868 \\
\hline 0.40 & 0.831 & 0.863 & 0.883 & 0.908 \\
\hline 0.45 & 0.907 & 0.926 & 0.937 & 0.952 \\
\hline 0.50 & 1.000 & 1.000 & 1.000 & 1.000 \\
\hline
\end{tabular}


Відібраний ризик відсотка неправильної відмови й відповідні звичайні нормативні відхилення або фактори $\mathrm{II}_{\Gamma}$ подані в таблиці 7.10.

Таблиия 7.10

\section{Ризик неправильної Звичайне нормативне Відповідна}

впевненість відмови відхилення (фактор II г) або рівень надійності)

\begin{tabular}{|c|c|c|}
\hline 0.30 & \pm 1.04 & 0.70 \\
\hline 0.25 & \pm 1.15 & 0.75 \\
\hline 0.20 & \pm 1.28 & 0.80 \\
\hline 0.15 & \pm 1.44 & 0.85 \\
\hline 0.10 & \pm 1.64 & 0.90 \\
\hline 0.05 & \pm 1.96 & 0.95 \\
\hline 0.01 & \pm 2.58 & 0.99 \\
\hline
\end{tabular}

Наступним етапом формування вибірки є визначення розміру вибірки за методом середнього значення на одиницю:

$$
n=\left(\frac{N \cdot U_{R} \cdot S_{x j}}{A}\right)^{2}
$$

де, $\mathrm{N}=$ розмір сукупності;

$\mathrm{U}_{\mathrm{R}}=$ звичайне нормативне відхилення з урахуванням бажаного ризику неправильної відмови;

$\mathrm{S}_{\mathrm{xj}}=$ оціночне нормативне відхилення сукупності;

$\mathrm{A}=$ бажане або заплановане виправлення 3 урахуванням ризику вибірки.

Так, у бюджеті України ці чотири фактори становлять 3.000, 1.96, 100 й 42.000 млрд грн. відповідно. Таким чином, розмір вибірки (статей доходів) становить 196, розраховується в такий спосіб:

$$
n=\left(\frac{3,000 \cdot 1.96 \cdot 100}{42,000}\right)^{2}=196
$$

Тобто, для дослідження дохідної частини державного бюджету необхідно дослідити 196 основних джерел їх формування 
за видами та особливостями формування та надходження.

Після збору аудиторських доказів слід перейти до процесу їх аналізу для створення необхідної бази для розробки наступних висновків і рекомендацій.

Що стосується етапу аналізу результатів ревізії (перевірки) та переробки їх в акти, довідки або протоколи, то про порядок його здійснення в існуючій в Україні нормативній базі, що регулює питання державного аудиту сказано дуже мало. Робоча документація може бути оформлена у вигляді простих записів, таблиць групуванням цифрових чи інших даних та їх аналізом тощо.

При аналізі чи розробці аудиторських доказів основною характеристикою того чи іншого доказу повинна бути його достатність. Тобто обсяг доказів повинен давати можливість сформувати думку щодо цілі аудиту.

Оцінюючи достатність аудиторських доказів, завжди необхідно ставити питання та давати на нього відповідь - чи є зібрані докази достатніми для того, щоб переконати пересічного громадянина в достовірності та обгрунтованості висновків аудиту ефективності.

При оцінці достатності доказу також необхідно брати до уваги наступні чинники:

- якість отриманих доказів;

- рівень істотності або значущості виявлених даних;

- ступінь ризику, пов'язаного 3 помилковістю зробленої думки;

- накопичений під час попередніх аудитів досвід щодо достовірності аудиторської документації;

- попередньо відоме ставлення клієнта до відповідної проблеми; 
- переконливість доказів при аудиті;

- витрати на отримання доказів у порівнянні з користю, яка отримана від них при їх використанні для підкріплення отриманих відомостей.

Аналіз аудиторських доказів має різноманітні моделі або методи: дослідження причинно-наслідкових зв’язків, порівняння поточної ситуації з минулими подіями, порівняльні дослідження різних варіантів або результатів. Аналіз доказів пов'язаний 3 оцінкою значущості знайдених фактів і з формуванням відповідей на питання аудиту.

Результати аудиторської перевірки виникають не випадково. Вони утворюються (виявляються) в процесі тестування з наступним аналізом його результатів. При цьому об’єкти тестування могли бути вибрані для дослідження відхилень від норм, виявлених у процесі перевірки.

Результати є доказами: вони репрезентують не просто випадкові події, але виключення зі стандартних правил. У ДФА вони представляють систематичні помилки або неточності, які нерідко трапляються у тих чи інших процесах.

Усі результати мають бути досліджені, аби на їх підставі можна було визначити:

1) критерії - очікуваний стандарт ефективності або нормативного регулювання;

2) стан - як йдуть справи насправді;

3) причини - чому не було витримано вимоги стандарту;

4) слідства - що з цього слідує. Інакше кажучи, наслідки існуючої різниці між тим, як повинні іти справи та тим, який стан в дійсності;

5) наслідки - якими $є$ можливі наслідки цього (втрата 
коштів, часу тощо);

6) висновки аудиту - хто або що несе відповідальність;

7) рекомендації - що саме аудитор рекомендує (якщо це можливо) здійснити організації для виправлення або покращання стану речей.

Критерій-це стандарти, на відповідність яким перевіряється ефективність діяльності. В аудиторських перевірках законності та нормативної відповідності ці стандарти зазвичай представлені незмінними правилами, нормами та процедурами. В аудиторських перевірках критерії тяжіють до меншої визначеності, лишаючись відкритим для суб’єктивної оцінки та трактування.

Причини недотримання стандартів, виявлені під час аудиторських перевірок нормативної відповідності, можуть бути такі:

1.Незабезпечення відповідності законодавчим та нормативним вимогам.

2.Невідповідність встановленим бюджетним обмеженням.

3.Відсутність належного обліку.

4.Відсутність моніторингу триваючих операційних процесів.

Причини невідповідності, виявлені в ході аудиторських перевірок ефективності діяльності, можуть бути такі.

1.Не визначені підходящі цілі.

2.Не розроблені операційні плани.

3.Не встановлені стандарти очікуваної ефективності діяльності.

4.Відсутність забезпечення відповідними людськими та матеріальними ресурсами.

5.Відсутність підготовки персоналу або нагляду за його діяльністю. 
6.Не розроблені або неналежним чином функціонують системи внутрішнього обліку.

Причиною відхилень від стандартів (вимог, норм), виявленою в обох типах аудиторських перевірок, може бути невживання керівництвом заходів, рекомендованих попередніми аудиторськими перевірками.

Таким чином, розробка та аналіз аудиторських доказів повинні бути практичною основою для звіту про аудит ефективності, а також що найважливіше, сформувати базу для наступних висновків, рекомендацій та пропозицій.

Основою методики фінансового контролю є нормативний підхід, тобто перевірка діяльності організації відносно дотримання правил здійснення фінансових i господарських операцій 3 державними коштами, тоді як проведення ДФА базується на аналітичних процедурах та оцінці економічних наслідків використання державних коштів. При цьому важливу роль відіграє аналіз систем управління, планування, моніторингу та контролю, що існують на об'єктах перевірки, їх здатність забезпечувати виконання запланованих результатів.

Отже, оцінка ефективності використання державних коштів повинназдійснюється на основі обраних критеріїв, що представляють свого роду «еталон», якому має відповідати діяльність об'єктів, що перевіряються. У процесі проведення ДФА слід використовувати такі методи збору фактичних даних, як анкетування, методичні правила проведення якого розроблені в роботі.

\section{Список використаних джерел:}

1. Аудит: підручник (в двох частинах) / За ред. Грушко B.І./ Брадул О.М., Шепелюк В.А, Ільіна С.Б., Юнацький М.О., Хорошенюк А.П., Брадул Т.В., 4-те вид. доп. і перероб. Київ: Ліра-К, 
2019. 324 c.

2. Бюджетний кодекс України. URL: https://zakon.rada.gov.ua/ laws/show/2456-17\#Text

3. Управлінський облік: навчально-практичний посібник. - 2-ге вид., перероб. і доп. / О.М. Брадул, В.А. Шепелюк. Київ: Кондор, 2017. 352 с.

4. Державний фінансовий контроль виконання бюджетних програм / T.I. Єфименко, I.Б. Стефанюк, Н.І. Рубан та ін. Монографія. Київ: НДФІ, 2004. 204 с.

5. Шевчук В.О. Про організацію державного фінансового контролю в зарубіжних країнах: Аналітична записка. Київ: НДФІ при Міністерстві фінансів України, 1999. 21 с.

6. Юргилевич С.В. Система державного фінансового контролю. Фінансовий контроль. 2002. №4. 